\title{
The Effect of Reflective Learning on Childbirth Care Competence of Midwifery Students
}

\author{
Lola Noviani Fadilah ${ }^{1}$ (D), Farid Husin ${ }^{2}$, Juntika Nurihsan³ ${ }^{3}$, Tria Giri Ramdani ${ }^{4}$ \\ ${ }^{1}$ Politeknik Kesehatan Kementerian Kesehatan Bandung, Bandung, Indonesia \\ ${ }^{2}$ Universitas Padjadjaran, Bandung, Indonesia \\ ${ }^{3}$ Universitas Pendidikan Indonesia, Bandung, Indonesia \\ ${ }^{4}$ Dinas Kesehatan Provinsi Jawa Barat, Bandung, Indonesia \\ Email: emailnyalola@gmail.com, farid_husin@yahoo.com, juntikanurihsan@upi.edu, triagiriramdani@yahoo.com
}

How to cite this paper: Fadilah, L.N., Husin, F., Nurihsan, J. and Ramdani, T.G. (2019) The Effect of Reflective Learning on Childbirth Care Competence of Midwifery Students. Open Journal of Nursing, 9, 209220. https://doi.org/10.4236/ojn.2019.93021

Received: January 28, 2019

Accepted: March 1, 2019

Published: March 4, 2019

Copyright $\odot 2019$ by author(s) and Scientific Research Publishing Inc. This work is licensed under the Creative Commons Attribution International License (CC BY 4.0).

http://creativecommons.org/licenses/by/4.0/

\begin{abstract}
Background: The skills of midwives in childbirth care competence are still inadequate. This problem is influenced by limitation experience of midwifery students of childbirth care in the field of practice area. That condition related to the proportion of midwifery students and case of childbirth woman was an imbalance. Midwifery students must prepare this competence in an education with childbirth care experience from practice in the laboratory and in the field of practice. Reflective learning is an appropriate learning method that uses experience as the basis of learning to improve childbirth care competence of midwifery students. Objective: This study is to analyze the effect of reflective learning implementation in childbirth care practice to improve students' competence. Method: This research uses quasi-experimental design with non-equivalent control group design. The respondents were midwifery students in the fourth semester who had experienced the theory of childbirth care. There were totally 64 samples, 34 samples for treatment group and 30 samples for control group. Data were analyzed by using unpaired $t$ test, Mann Whitney $U$ and linear regression. Results: The respondents were homogeny in motivation and grade point of average (GPA). The improvement of childbirth care competency is influenced by treatment of 19.064 with $\mathrm{R}^{2}=57.7 \%$. Conclusion: The implementation of reflective learning in childbirth care practice affected the improvement of students' competence.
\end{abstract}

\section{Keywords}

Reflective Learning, Competence of Childbirth Care, Midwifery Students

\section{Introduction}

Quality of midwifery services requires midwives who have professional skills and 
emotional intelligence [1]. The quality of midwife education is needed to form midwives who can provide quality services. Current conditions are faced with insufficient skills in midwives to support maternal and neonatal health. Data show that only $22 \%$ of countries have the potential to educate midwives and that the other $78 \%$ have serious shortcomings in midwife education, so that the impact on maternal and infant mortality is still high. One of the factors that cause limited capacity in educating midwives is lacking in practicing. Thus, WHO in one component of the Global Call Action appealed to fight for the quality of midwifery education [2]. The quality of midwife services must be supported by the competency of a standardized midwife. Competence is a set of intelligent actions, full of responsibilities that a person has as a condition to be considered capable by the community in carrying out tasks in certain fields of work. Midwife competency is the ability of midwives to do a task and work based on knowledge, skills, and work attitudes [3]. In accordance with the competency standards of midwives and according to International Confederation of Midwives (ICM), childbirth care is one of the core competencies of midwives [4]. Thus, increasing the competence of midwives in childbirth care must fulfill the aspects of knowledge, skills and work attitudes. During the education period, midwives are prepared to master these competencies and the midwifery education institutions are required to facilitate students in their achievements. Competence in childbirth care is a midwife's core competency which must be provided with high quality, so that the care provided is safe for the patient [3]. The achievement of this competency must be supported by optimal learning at the theoretical level, in the laboratory practice and in the field practice [5]. Competency conditions for midwife graduates are currently lacking in terms of childbirth care. This can be explained by the results of research on childbirth care learning which show data that as many as $20 \%$ of doctors and $17 \%$ of senior midwives believe that midwife graduates have less competence in childbirth especially in normal labor management. The results of the study also show that $91.2 \%$ of students, $52.5 \%$ of midwives, and $41.1 \%$ of obstetricians consider that there is still little learning allocation about childbirth care in education [6].

The problem of the limitations of learning childbirth care in education is not inseparable from the fact that students still inexperienced in childbirth care, especially on field of practice. This is related to the number of students who are not comparable with the amount of field practice which has an impact on the effectiveness of the clinical learning process. This condition causes difficulty in achieving competency in clinical practice and will have an impact on the quality of health services. Efforts to overcome these problems are the making of various models of clinical education that are applied to health education in the world [7]. Learning experiences in childbirth care on field practice are influenced by organizational learning experiences and laboratory practices. This is a series of continuous learning cycles that will condition the readiness of students in the clinical learning experience on field practice. Therefore, learning in both the 
classroom, laboratory, and practice area is very important using methods that can facilitate the experience of training in proper labor [5]. Experience will increase self-confidence, comfort, and reduce fear as a result of the procedures performance to clients so the need for practical experience for students [8]. Characteristics of students in early adulthood are flexible, open, adaptive, and individualistic ways of thinking. This way of thinking is characterized by the ability to deal with uncertainty, contradiction, imperfection, instability, and compromise. Thus, students are required to be responsible and independent learning so that learning can be self-directed, gathering experience, and centered on problem solving [9]. Specific aspects that need to be emphasized in learning for midwife students are the midwife autonomy formation as clinical decision makers so that requires a learning process that can form critical thinking patterns. One of the appropriate lessons is experiential learning which emphasizes that experience becomes the main actor in the learning process and emphasizes that it is what differentiates experiential learning theory (ELT) from other learning theories [10]. The nature of ELT is a learning cycle known as Kolb's cycle. The cycle has four components, namely, 1) concrete experience, 2) observation reflection, 3) abstract conceptualization, and 4) active implementation [11] [12]. In practice, the effectiveness of ELT comes not only from positive experiences, but also from effective reflection [12]. Effective reflection is the key of ELT and part of learning. Thus, specifically the learning method used to unlock the ELT is by the reflective learning method [13].

Reflective learning is a learning approach with a constructive paradigm that involves a process of reflection about what is learned, what is understood, what is thought including what will be done later. In addition, it is also interpreted as an act of describing oneself about what is felt, seen and known, how to form new experiences, increase understanding or increase knowledge in learning, as well as what will be done/thought next. The purpose of this learning approach is to avoid mistakes in the future, so that they can improve performance. Reflective learning is the core of education and includes meaningful learning (meaning learning) [13].

Reflection is a method that uses experience as a basis and intrinsically contains the concept of critical thinking. The practice of reflection is an important component for forming self-awareness, skill, and autonomy formation as midwifery practitioners [14] [15] [16]. Every educator must facilitate the application of the principles of adult learning to his students. The application of these principles can be done by applying reflection practices that aim to form the power of critical analysis and evaluation of learning or practice. As a professional health worker, a midwife must develop and improve the application of theory into practice to maintain the quality of care [17]. The goal of reflective practice is to shape professional knowledge, understand in depth-practical learning, so that it can be internalized naturally, mastered, and can be done easier [18]. The results of quantitative studies show that there is a correlation between flexibilities and professional competencies [19]. The appropriate type of reflection used in child- 
birth care cases is reflection on action, that is, students reflect retrospectively care during labor, which can describe the personal emotional condition of the student. Reflection can be done orally or written. By writing, the structure of reflection will be clearer and there will be real progress from the level of complexity of the cognitive and psychomotor areas of students in the delivery room [20]. The reflection is written in the birth diary. The study of the effects of writing reflections on midwifery student learning and professional development shows that there is significant progress from the level of complexity of the cognitive and psychomotor areas in students who practice reflection in the delivery room [19]. The appropriate model is needed to facilitate the process. Gibbs "reflection model" is often used for reflection on action [16]. Gibbs' reflection cycle is a development of the experiential learning cycle, which suggests that theory and practice complement each other in a circle. The Gibbs' model presents basic questions that can help structure reflection and as one of the previous models used to support continuous assessment in the practice area. Thus, the use of the Gibbs' model is relatively easier and better known to be chosen as a reflection model [14]. In addition to the application of the right method, there are other important factors that can influence the learning process and results, namely motivation in learning. Student grade point of average (GPA) as achievement in learning is one of the pictures of learning motivation of students [21]. Thus, students' learning motivation and students' grade point become other factors that can become confounded in achieving self-confidence and competency in childbirth care.

\section{Methods}

\subsection{Study Design}

The study was a quasi-experimental method in the form of non-equivalent control group design during two months. In this study there were treatment and control groups that were not randomly selected. The purpose of this study is to analyze the effect of reflective learning implementation in childbirth care practice to improve student's competence.

\subsection{Population and Sample}

The population in this study was all students of Bandung Midwifery Department of Politeknik Kesehatan Kementerian Kesehatan Bandung. The sample in this study was the fourth semester midwifery students in Bandung Midwifery Department of Politeknik Kesehatan Kementerian Kesehatan Bandung, who had passed the care course and would carry out midwifery clinical practice. The respondents are midwivery students who will do the clinical practices already determined the Division of the Group and places the practice (11 practices land) permanently by educational institutions so that researchers could not join the arrange placement and number of students. A sample of 64 people was taken in total sampling (there were the number of respondents already meet minimum 
sample for the study of quasi experiment that is a minimum of 30 sample per group) and divided into two groups, namely the treatment group (34 respondent in 6 practices land) and control group (30 respondent in 5 practices land) which were differentiated based on the quantity of childbirth care cases on the practice land to be used. The treatment group is a student who is placed on the practice land that are identified as land practices with the number of cases childbirth care more than the control group.

\subsection{Research Procedure}

The flow of research starting from the preliminary study and analysis of problems, development of instruments and instrument testing, filing of permits and research ethics review (Ethical Approval Number: 463/UN6.KEP/EC/2018 from Universitas Padjadjaran Research Ethic Committee).

The next step is data retrieval. Data on learning motivation and grade point of average (GPA) were taken as characteristic of respondents. Questionnaire motivation for learning to practice childbirth care uses a Likert scale consisting of 30 statements (with Cronbach Alpha 0.76). The GPA obtained from secondary data.

In the control group, pretest of childbirth care competency care were carried out in the laboratory using a birth checklist and feedback was given on the results of the pretest according to the standards that had been used for practical guidance. Furthermore, respondents conducted clinical practice by giving feedback on their performance in childbirth care for four weeks. After the $4^{\text {th }}$ week, the practice was carried out in the posttest of childbirth care competencies.

In the treatment group, pretest of childbirth care competency was carried out in the laboratory using the childbirth care checklist and feedback from the pretest results was given. Furthermore, treatment was given in the form of applying reflective learning to practical learning in the laboratory (for 5 days) by practicing various cases of childbirth care equipped with reflective writing using the Gibb's Model and given reflection feedback. Then, on the practice site (for 4 weeks) students practiced reflective writing using the Gibb's Model and were given feedback on each reflection of the childbirth care case carried out. This intervention was carried out based on the design of the application of reflective learning which was compiled and validated by experts. After the $4^{\text {th }}$ week the practice was carried out in the posttest of childbirth care competencies.

After collecting the data the next step is the analysis of the data.

\subsection{Data Analysis}

The analysis of characteristic of respondent (in the form of numerical data) which is normally distributed by using an unpaired t-test to find out the differences between the treatment and control groups. The results of the normality test for the pretest and posttest scores of childbirth care competencies and the percent enhancement in the competency score were not normally distributed. 
Hence, the Mann-Whitney $U$ test was conducted to find out the differences in pretest and posttest and percent enhancement of competency score between the treatment and control groups. After all, multivariate analysis was performed by linear regression to determine the effect of treatment on childbirth care competencies.

\section{Results}

The results of characteristics of respondent in the form of learning motivation and GPA are in Table 1, which shows homogeneous respondents. The difference in competency score and percent of competency score enhancement is in Table 2. That table which shows that there are significant differences $(\mathrm{p}<0.05)$ between competency scores in the treatment group and the control group and percent enhancement of competence score in the treatment group reaches $214.5 \%$ while in the control group $63.12 \%$. The analysis results of treatment effect in the form of reflective learning implementation on increasing labor delivery competencies are in Table 3 which shows that increased competency is influenced by the application of reflective learning at 19.064 with $\mathrm{R}^{2}=57.7 \%$. This means that the increase in student competence $57.7 \%$ is influenced by the implementation of reflective learning. In addition, the value of the coefficient $B$ on the application of reflective learning is 19,064 , which is positive; this means that the more towards the treatment there will be an increase in competence.

\section{Discussion}

\subsection{Characteristics of Respondent}

The characteristics of the respondents in this study consisted of two data, namely motivation and student GPA. Respondents in this study were students who had gained learning experience in the theory and practice of childbirth care both in the classroom, laboratory and conducting field study practice to observe and practice micro skills in childbirth care on practical land. Thus the respondents' equality analysis was carried out on aspects of learning motivation for childbirth care and GPA. The results presented as follows.

Table 1 shows that there is no difference $(\mathrm{p}>0.05)$ motivation and grade point of respondents between the treatment and control groups. Thus, the two

Table 1. Characteristics of respondent.

\begin{tabular}{cccc}
\hline \multirow{2}{*}{ Characteristics of respondent } & \multicolumn{2}{c}{ Groups } & \multirow{2}{*}{$\mathrm{p}^{*}$} \\
\cline { 2 - 3 } & Treatment $(\mathrm{n}=34)$ & Control (n=30) & \\
\hline Motivation & & & \\
$\mathrm{X}(\mathrm{SD})$ & $71.8(8.1)$ & $72.2(8.3)$ & 0.849 \\
Grade Point of Average (GPA) & & & \\
$\mathrm{X}(\mathrm{SD})$ & $3.1(0.23)$ & $3.14(0.22)$ & 0,468 \\
\hline
\end{tabular}

Remark: *: unpaired t test. 
research groups have equivalent characteristics. This shows that the two groups can be compared. Learning outcomes in childbirth care in the form of student competence in providing childbirth care are influenced by various internal and external factors from students and externally from the learning environment. Learning motivation and GPA are important internal factors to be studied besides physical and mental interest and readiness [22]. Of the many motivations that play a role in human life, motivation achieves an important role. Motivation is closely related to efforts to achieve an achievement, the goal of success in every competition [23]. In learning, motivation is required. Motivation is sincerity or the driving force of someone to do better than what was previously made or achieved or made by or achieved by others. A person who has strong achievement motivation tends to make various efforts to be able to master his field of learning [24]. Motivation relates to persevere in trying so that with high learning motivation, students will be motivated to carry out learning activities, it will always follow learning and learning achievement will be easily achieved [21] [25].

Learning achievements are preferred in the world of education. Achievement can be interpreted as the results obtained because of the learning activities carried out. Learning achievement is a thing that cannot be separated from learning activities, because learning is a process while achievement is the result of the learning process [23]. Performance index is a picture of thinking ability/level of intelligence, even though the evaluation of learning based on the principle of complete learning has not been able to predict student competencies. In addition, grade point is also an effort to generate learning motivation and can describe learning motivation [21]. Both of these data are other factors that can influence the learning outcomes other than the applied learning methods, so it is important to study them as characteristics of the respondents.

\subsection{Differences in Competence before and after Treatment}

The results of the labor competency analysis are presented in Table 2 below.

Table 2. Differences in competence before and after treatment.

\begin{tabular}{|c|c|c|c|}
\hline \multirow{2}{*}{ Competence } & \multicolumn{2}{|c|}{ Groups } & \multirow{2}{*}{$\mathrm{p}^{*}$} \\
\hline & Treatment $(n=34)$ & Control $(n=30)$ & \\
\hline \multicolumn{4}{|l|}{ Pretest } \\
\hline Median & 31.8 & 59.1 & $<0.001$ \\
\hline Range & $0-68.2$ & $4.5-86.4$ & \\
\hline \multicolumn{4}{|l|}{ Posttest } \\
\hline Median & 94.4 & 88.9 & 0.011 \\
\hline Range & $78.6-100$ & $66.7-100$ & \\
\hline \multicolumn{4}{|c|}{ Percent of pretest-posttest score enhancement } \\
\hline Median & 214.5 & 63.12 & $<0.001$ \\
\hline Range & $40-2022.2$ & $-8.25-1504.4$ & \\
\hline
\end{tabular}

Remark: *: Mann-Whitney U Test. 
The competency score of the control group is higher than the experimental group. This condition is possible with the average learning motivation and a grade point in the control group is higher than the treatment group. The grade point in the evaluation of conventional learning methods can predict the achievement of competence, but it differs from the complete learning method which states that the achievement index is not certain to predict competency [26]. This increase in competency scores shows that the application of reflective learning is effectively used in practical learning in the laboratory and in field of clinical practice. This application can condition practical learning in the laboratory with a variety of practice settings and the variation of the case is equated with the real conditions on the practice land. In addition, the response in this study already has practical experience and is a repetition of practices both in the laboratory and in field practice. It will facilitate learning and the formation of student competencies, so as to spur an increase in competency scores in the treatment groups. In addition, the increase in maternity care competencies in the treatment group shows that the application of reflective learning to the practice of childbirth care is an important feature of experiential learning especially in clinical practice. Reflection is an experiential learning tool developed based on experience [27]. Reflection is a learning process by looking at previous experiences to get new perspectives and determining future behavior [28]. Thus, the student has a new experience in the practice of childbirth care, so he will learn from that experience to be able to change their mindset and behavior with respect to experiences that have already been experienced and improve their practice in the future that they can improve the development of understanding in professional practice [17].

Other factors that influence the improvement of competency are also related to the ability of the facilitator, in this case the supervisor of practice in the laboratory as well as in the practice area, in making feedback on the reflection that is done. In this study, feedback was taken on reflection that was carried out directly, so that the reflections carried out illustrated substantial accuracy in ensuring effective and safe performance in childbirth care [29] [30]. This will determine the achievement of increasing competence and performance and can support the effectiveness of applying reflective learning. In another study it was stated that writing reflection will be effective and will lead to better performance and encourage development into reflection if it is associated with experiences that are relevant, clear, and useful for learning, flexible in achieving the learning needs of individuals, guided by reflective masters learning, given feedback, judged by qualitative criteria, discussed with friends and mentors, implemented in a safe learning environment, and supported by the availability of time for reflection and feedback [31] [32]. In this study, the practice advisers were given training in advance in provide feedback and reflection assessment so that it can facilitate the development of student competencies in practice in the laboratory. The use of an appropriate reflection model, namely the Gibbs' Model in reflection on action 
practice in labor delivery competencies can also support the achievement of increased competence [14]. Reflection is a pedagogical strategy for transforming theory into practice. The approach to using reflection will improve clinical learning and develop reflection skills [33]. The ability to reflect is related to clinical performance, reflection contributes to improving clinical performance [34]. Furthermore the results of the study show that Reflection explains success or failure and facilitates procedural deepening and useful actions to practice in the future [16].

\subsection{The Effect of Reflective Learning Application on the Practice of Childbirth Care on Student Competency Improvement}

The result analysis of treatment effect on improving student competence are presented in Table 3.

Thus, increasing competency is not only influenced by the application of reflective learning, but there are other factors that influence the increase in these competencies. Competence is the ability to demonstrate high performance effectively in various cases and context situations. The formation of these competencies needs to be prepared to form practitioners who are able to use their knowledge, skills and responsibilities in providing high quality care. There are several factors that influence performance in a competency, they are stated as follows: expectations of educational institutions, expectations of colleagues in profession, expectations of professional organizations and expectations of individuals themselves. In addition, there are also other additional factors, namely attitudes and senior expectations, work environment and quality of communication in the practice environment. Placement of practice on field practice can also affect student performance. Other studies suggest that personality, individual background, experience in providing care, field practice environment can also affect performance [35]. In addition, high performance is also influenced by honesty, decision making, work habits, psychological stability and adaptability, anxiety and circadian rhythm [36] [37]. The application of reflective learning in the practice of childbirth care can be an alternative solution to facilitate the problems in the inadequate competence of midwives in childbirth care. In its implementation, reflective learning does not require additional lecturers as practical

Table 3. The effect of reflective learning application on the practice of childbirth care on student competency improvement.

\begin{tabular}{ccccc}
\hline Variable & Coefficient B & S.E (B) & t & p $^{*}$ \\
\hline $\begin{array}{c}\text { Competency enhancement } \\
\begin{array}{c}\text { Percentage of pretest-posttest score } \\
\text { enhancement }\end{array}\end{array}$ & 0.051 & 0.008 & 6.331 & $<0.001$ \\
Reflective learning implementation & 19.064 & 4.410 & 4.322 & $<0.001$ \\
Constanta & 30.140 & 3.194 & 9.437 & $<0.001$ \\
\hline
\end{tabular}

Remark: *: Linear regression Test with $\mathrm{R}^{2}=0.577$. 
guides/facilitators and does not require large costs, so that it is effective and efficient enough to be implemented. This application only requires integration in the curriculum and the commitment of the supervisors and students in the implementation.

\section{Conclusion}

There is an influence of the implementation of reflective learning on the practice of childbirth care towards improving student competence which can be implemented as an alternative way to improve labor competency care for students. Further research is needed at different places, to different students and with different practice guides, so that this research can be generalized. In addition, further research can also be developed on competencies associated with other internal and external factors, so that many factors can be explored more deeply.

\section{Conflicts of Interest}

The authors declare no conflicts of interest regarding the publication of this paper.

\section{References}

[1] Byrom, S. and Downe, S. (2010) "She Sort of Shines": Midwives' Accounts of "good" Midwifery and "Good” Leadership. Midwifery, 26, 126-137. https://doi.org/10.1016/j.midw.2008.01.011

[2] International Confederation of Midwife (ICM), WHO and UNFPA (2014) Fact Sheet: The State of the World's Midwifery 2014.

[3] Indonesia, P.P.I.B. (2014) Standar Kompetensi Bidan Indonesia. IBI, Jakarta.

[4] ICM (2013) International Confederation of Midwives Essential Competencies for Basic Midwifery Practice 2010 Revised 2013.

[5] Rostati, T., Ilyas, J., Purwaningsih, D., Fadilah, L.N. and Sriyanti, C. (2011) Panduan Pembelajaran Praktik Klinik Kebidanan dengan Pendekatan Preceptorship dan Mentorship. Pusat Pendidikan Tenaga Kesehatan Kementerian Kesehatan, Jakarta.

[6] Schytt, E. and Waldenström, U. (2012) How Well Does Midwifery Education Prepare for Clinical Practice? Exploring the Views of Swedish Students, Midwives and Obstetricians. Midwifery, 29, 1-8.

http://dx.doi.org/10.1016/j.midw.2011.11.012

[7] Nuzuliana, R., Diniyah, K. and Herfanda, E. (2015) Gambaran Pelaksanaan Bedside Teaching Pada Praktik Klinik Kebidanan Prodi Kebidanan Jenjang Diploma III Stikes Aisyiyah Yogyakarta. Jurnal Kebidanan dan Keperawatan Aisyiyah, 11, 151-157.

[8] Dahlen, H.G. and Homer, C.S. (2008) What Are the Views of Midwives in Relation to Perineal Repair? Women and Birth, 21, 27-35. https://doi.org/10.1016/j.wombi.2007.12.003

[9] Latipah, E. (2017) Pengaruh Strategi Experiential Learning Terhadap Self Regulated Learning Mahasiswa. Humanitas. Jurnal Psikologi Indonesia, 14, 41-56. https://doi.org/10.26555/humanitas.v14i1.4547

[10] Siswanto, B.T. (2011) Pendidikan Vokasi, Work-Based Learning, dan Penyelenggaraan Program Praktik Pengalaman Lapangan.

[11] Schenck, J. and Cruickshank, J. (2015) Evolving Kolb: Experiential Education in the 
Age of Neuroscience. Journal of Experiential Education, 38, 73-95. https://doi.org/10.1177/1053825914547153

[12] Kolb, A.Y. and Kolb, D.A. (2009) Experiential Learning Theory: A Dynamic, Holistic Approach to Management Learning, Education and Development. The SAGE Handbook of Management Learning, Education and Development.

[13] Gagnon, G.W. and Collay, M. (2001) Designing for Learning: Six Elements in Constructivist Classrooms. Corwin Press, California.

[14] Gallagher, L. (2017) An Evaluation of the Appropriateness and Effectiveness of Structured Reflection for Midwifery Students in Ireland. Nurse Education in Practice, 22, 7-14. https://doi.org/10.1016/j.nepr.2016.11.003

[15] Bass, J. (2016) Promoting Retention, Enabling Success: Discovering the Potential of Student Support Circles. Nurse Education in Practice, 20, 109-116. https://doi.org/10.1016/j.nepr.2016.07.002

[16] Nicol, J.S. and Dosser, I. (2016) Understanding Reflective Practice. Nursing Standard, 30, 34-42. https://doi.org/10.7748/ns.30.36.34.s44

[17] Black, P.E. and Plowright, D. (2010) A Multi-Dimensional Model of Reflective Learning for Professional Development. Reflective Practice, 11, 245-258. https://doi.org/10.1080/14623941003665810

[18] Tilbrook, V. and Catt, L. (2015) Critical Reflection through Creative Expression: How to Develop Reflective Skills for Professional Practice. Women and Birth, 28, S55. https://doi.org/10.1016/j.wombi.2015.07.174

[19] Ekelin, M., Kvist, L.J. and Persson, E.K. (2016) Midwifery Competence: Content in Midwifery Students Daily Written Reflections on Clinical Practice. Midwifery, 32, 7-13. https://doi.org/10.1016/j.midw.2015.10.004

[20] Bäck, L. (2017) Developing Competence and Confidence in Midwifery-Focus Groups with Swedish Midwives. Women and Birth, 30, e32-e38. https://doi.org/10.1016/j.wombi.2016.08.004

[21] Suprihatin, S. (2015) Upaya guru dalam meningkatkan motivasi belajar siswa. Jurnal Pendidikan Ekonomi UM Metro, 3, 73-82. https://doi.org/10.24127/ja.v3i1.144

[22] Ahmad Susanto, M.P. (2016) Teori belajar dan pembelajaran di sekolah dasar. Kencana.

[23] Retnowati, D.R., Fatchan, A. and Astina, I.K. (2016) Prestasi akademik dan motivasi berprestasi mahasiswa S1 pendidikan geografi universitas negeri malang. Jurnal Pendidikan: Teori, Penelitian, dan Pengembangan, 1, 521-525.

[24] Fatchurrohman, R. (2017) Pengaruh motivasi berprestasi terhadap kesiapan belajar, pelaksanaan prakerin dan pencapaian kompetensi mata pelajaran produktif. Innovation of Vocational Technology Education, 7.

[25] Von Culin, K.R., Tsukayama, E. and Duckworth, A.L. (2014) Unpacking Grit: Motivational Correlates of Perseverance and Passion for Long-Term Goals. The Journal of Positive Psychology, 9, 306-312. https://doi.org/10.1080/17439760.2014.898320

[26] Siddaiah-Subramanya, M., Smith, S. and Lonie, J. (2017) Mastery Learning: How Is It Helpful? An Analytical Review. Advances in Medical Education and Practice, 8, 269. https://doi.org/10.2147/AMEP.S131638

[27] Boud, D., Keogh, R. and Walker, D. (1985) Promoting Reflection in Learning: A Model. In Boud, D., Keogh, R. and Walker, D., Eds., Reflection: Turning Experience into Learning, Routledge, London, 18-40.

[28] Koole, S., et al. (2011) Factors Confounding the Assessment of Reflection: A Critical Review. BMC Medical Education, 11, 104. 
https://doi.org/10.1186/1472-6920-11-104

http://www.biomedcentral.com/1472-6920/11/104

[29] Eva, K.W. and Regehr, G. (2011) Exploring the Divergence between Self-Assessment and Self-Monitoring. Advances in Health Sciences Education, 16, 311-329. https://doi.org/10.1007/s10459-010-9263-2

[30] Driessen, E., et al. (2003) Use of Portfolios in Early Undergraduate Medical Training. Medical Teacher, 25, 18-23. https://doi.org/10.1080/0142159021000061378

[31] Wald, H.S., et al. (2009) Reflecting on Reflections: Enhancement of Medical Education Curriculum with Structured Field Notes and Guided Feedback. Academic Medicine, 84, 830-837. https://doi.org/10.1097/ACM.0b013e3181a8592f

[32] Van der Vleuten, C.P., et al. (2012) A Model for Programmatic Assessment Fit for Purpose. Medical Teacher, 34, 205-214. https://doi.org/10.3109/0142159X.2012.652239

[33] Velo, K. and Smedley, A. (2014) Using Reflection to Enhance the Teaching and Learning of Midwifery Students. British Journal of Midwifery, 22, 129-133. https://doi.org/10.12968/bjom.2014.22.2.129

[34] Embo, M., et al. (2015) Relationship between Reflection Ability and Clinical Performance: A Cross-Sectional and Retrospective-Longitudinal Correlational Cohort Study in Midwifery. Midwifery, 31, 90-94. https://doi.org/10.1016/j.midw.2014.06.006

[35] White, K.A. (2009) Self-Confidence: A Concept Analysis. Nursing Forum. Wiley Online Library. https://doi.org/10.1111/j.1744-6198.2009.00133.x

[36] Wood, R. and Power, C. (1987) Aspects of the Competence-Performance Distinction: Educational, Psychological and Measurement Issues. Journal of Curriculum Studies, 19, 409-424. https://doi.org/10.1080/0022027870190503

[37] Stupple, E.J., et al. (2017) Development of the Critical Thinking Toolkit (CriTT): A Measure of Student Attitudes and Beliefs about Critical Thinking. Thinking Skills and Creativity, 23, 91-100. https://doi.org/10.1016/j.tsc.2016.11.007 